\title{
Humour as an information resource in the media ${ }^{1}$
}

\author{
Liliya Duskaeva \\ Saint-Petersburg State University, Russia \\ 1.duskaeva@spbu.ru
}

In recent decades, humour has become a popular means of expressing attitude to the world, an instrument of impact on the audience in mass communication. Even cursory observations of media texts show that the comic acts as a communicative resource, which is, firstly, due to its wide range of functions in the media discourse. Secondly, there is a well-established trend for using humour in mass media. Thirdly, it is due to the apparent simplicity of using humorous means to attract attention. The media have a tendency to simplify the forms and means selected to achieve communicative goals, and humour, which often involves play and pretence, seems to be a relevant means of accomplishing such a task. It is humour that facilitates understanding of what has been said, it undoubtedly attracts the attention of the audience and involves it in a kind of game. At the same time, humour has a deep internal social content hidden behind the playful message. Since humour is a tool for deep social criticism, the media seek to use humour to the greatest extent possible. However, the peculiar trend to use a comic style in mass media communication often leads to its inappropriate (and unprofessional) use (Kostomarov 1971). The depth of controversy is being replaced in the media with trolling, which destroys social interaction. The use of bodily, lower stratum topics tabooed in public communication deprives media rhetoric of wit and fills it with vulgarity. Joking is inappropriate when it comes to reporting about tragic situations as it turns speech into mockery, while the desire to win a political dispute via humour tends to result in an insult. Finally, humour takes on extremely aggressive forms when it turns into a means of expressing extremist ideas. As media communication is characterised by a high social and normative role, it requires professional qualifications to deal with it.

The influence of comic communicative behaviour on the functioning of modern media is enormous, the effect of using such means is essential, thus a systematic study of speech practices of using the comic in the media seems to us socially significant. It is crucial to understand the humorous content in social communication as well as to determine how the social characteristics of the target audience influence the composition of the comic media text. A special issue of the journal, prepared by the members of the medialinguistic commission of the International Committee of Slavists, is devoted to the study of the forms, methods and

\footnotetext{
${ }^{1}$ The study was carried out with the financial support of the RSF: grant 19-18-00530 "Humour as a communicative resource in the digital news environment".
} 
techniques of humour in the media texts written in three Slavic languages. The East Slavic languages are represented by Russian, the West Slavic languages are exemplified by Slovak, while the South Slavic languages are represented by Bulgarian.

Based on the analysis of media language, the authors are looking for answers to the question of how the use of humour in web-based media texts helps to generate the persuasive effect on mass audience. In the last decade, as a result of the widespread adoption of new media platforms, there has been a significant evolution in the types, methods and techniques of social communication. Comic social and speech behaviour in mass communication actively transforms the traditions of communicative behaviour in it and creates its new rituals and patterns. To express humour, mass media employ a gamut of verbal and non-verbal means and use them in accordance with specific scenarios. To convey humour, the media mobilise a wide range of means, both verbal and non-verbal, according to certain patterns. It is important to emphasise that these rules are not something permanently established, but are adjusted to the configuration of each situation in which humour is used.

Previously conducted studies of humour in the media testify that there are a few tendencies predetermining the logic of investigating its linguistic mechanisms. Firstly, the unit of analysis has been gradually enlarged (attention has shifted from individual words to compositionally structured speech units - discourse genres and texts). Secondly, the range of analysed tools has expanded. Along with verbal means that form the structure of mass media texts, researchers have begun to study the humorous means of different semiotic nature. Thirdly, various extralinguistic factors predetermining the use of humour have come to the fore. ${ }^{2} \mathrm{We}$ believe that our study of humour in the mass media of various types is carried out in line with academic traditions. However, the statement of the problem proposed in the issue is fundamentally new. Articles aimed at analysing the use of various types of the comic in the mass media enable us to show its social functions, value content and language mechanisms in social communication. Thus, in order to show the humour practices used in institutional variants of online mass media, the authors of the articles presented in the issue most often adopt an interdisciplinary medialinguistic approach.

There is no doubt that the study of the use of humorous means in the most actively developing sphere - the media - will supplement existing ideas with knowledge about hidden ways of using humour, about previously unknown illocutionary meanings of its means of expression, and will clarify our ideas about the connections between the verbal and the visual conveying humour. This leads to the necessity of addressing the stereotypical practices, consistently reproducing the comic effect. In order to use the language in this sphere of communication effectively and to teach the use of the language successfully, it is necessary to understand not only the most important communication situations, but also the productive types, forms, and methods of professional communicative activity as well as multimodal communicative actions that are used to achieve certain communicative goals. The results of this research are extremely significant for media speech that is actively expanding its borders. The discovery of effective humorous communicative acts in different web segments provides rich material for understanding the sociocultural conditioning of text organisation.

The paper entitled "Terminology as a source of misunderstanding: English and Russian humour term systems" by Ekaterina Shcheglova and Ksenia Shilikhina introduces the problem of differences between the two sets of terminology. If these differences are not recognised by scholars, they can potentially lead to confusion and misunderstanding in academic discourse. By analysing dictionary definitions and scholarly writings, the authors demonstrate how "naïve"

${ }^{2}$ Attardo 2017; Attardo 2020; Brzozowska, Chłopicki 2020; Grochala, Dembowska-Wosik 2012, Grochala 2014, Tay 2014, Marone 2015, Filani 2016, Laineste, Voolaid 2016, Marone 2016, Mifdal 2016, Pahl 2016, Steir-Livny 2016, Weitz 2016, 2017, Vásquez 2019; Duskaeva, Shcheglova 2020, Vasileva 2019, Vasileva \& Ivanova 2021a. 
understanding of the terms differs from their scholarly use in two languages. Also, they demonstrate that for the English-speaking humour researchers the word humour functions as the umbrella term which can designate any form or genre of non-serious communication. In contrast, Russian scholars tend to use the word комическое (the comic) as the core term. The term humour is used by Russian researchers in a much narrower sense - it refers to something funny and entertaining. Such significant terminological differences lead to difficulties in translation and impede understanding.

The article by Lilliya Duskaeva reveals the typology of socio-communicative actions in two types of the Russian mass media - sociopolitical and business ones. The analysis has shown the variability of ironic illocution in the media language, associated with differences in its axiological content in different media. In sociopolitical media, the texts most often used are sarcastic, ridiculing a political opponent, contrasting the position of like-minded people and opponents. In Russian business publications, the most widely used humorous means is irony, which allows the narration to be carried out remotely, with the narrator being extradiegetic. The analysis shows that meta-textual and para-textual components of media texts play an important role in conveying a variety of illocutionary meanings, and this feature is firmly rooted in the multimodal nature of the mass media text.

The article by Viktoria Vasileva and Liubov Ivanova analyses humour in Evening Meduza, a Russian news web-based resource. The authors reveal the mechanisms of humour creation in separate news messages and in the paratextual organisation of each newsletter issue. This article as well as previous work of the authors (Vasileva 2017; Vasileva \& Ivanova 2020) suggest new, original methods of humour research. The analysis of Evening Meduza shows that humour deepens the content of a news event and clarifies it.

Tatyana Chernyshova's paper explores the means and ways of creating humorous effects in modern ironic media texts. The study is based on the texts published in the Russian newspapers Kommersant and Moskovsky komsomolets. The study is aimed at the componential analysis of the language means that create humorous effects in these media texts. The author describes the signals of irony as language play and as a socially marked type of communication. The analysis allows for the conclusion that contrast is the main tool used by journalists to create irony, and that such contrast can be found on both textual and sub-textual levels. Special attention is paid to the language means used in an ironic media text which led to the filing of a court case. The results of the analysis show that it is possible to redeem ironic media texts from legal risks, since the author's evaluative judgements expressed in an ironic manner cannot be assessed as true or false.

The article by Irina Dulebova and Linda Krajchovichova entitled "The humorous dimension of intertextual relations in contemporary Slovak creolised media text" deals with a highly contemporary, yet surprisingly understudied question of an increase in the number of comic elements in contemporary Slovak media. The authors of the article specify the causes of the phenomenon and focus on basic functions of humour in Slovak media while concluding that the intentions of social criticism were most often achieved through intellectual play, and most of the examples analysed show signs of considerable relaxation of social taboos. In the analysis, they focused on the use of intertextual elements in the process of creating a comic effect, including culturally significant names, universally known images and posters as well as intertextual references known across Slovakia. Attention was drawn to creolised texts that are becoming more and more popular in the contemporary Slovak media discourse and the audience of which should be "culturally capable" to decipher the intertextual play which may not be only verbal, but also visual. The analysis is performed on a representative sample of covers (as a classic example of a media creolised text) of one of the most popular Slovak magazine .týždeř over the past five years. The authors come to an interesting conclusion that one of the most widespread means of creating a humorous effect is the deliberate violation of the semantic or 
structural integrity of culturally significant intertextual codes, disrupting their stereotypical form by substitution (replacing), explication (adding), implication (removing) and contamination (linking) of original components. It was also paradoxical to discover that to allow readers to understand "intertextual riddles", Slovak authors predominantly provide the Slovak reader with significant cultural references not to Slovak, but European or world cultural space, raising other challenging questions which presume prospective research into the specifics of the creation and perception of the comic in contemporary Slovak linguistic space.

The question of using metaphors in Bulgarian mass media has already been discussed by researchers (see, for example, Stoyanova 2015). This paper mentions yet another specific feature of using metaphors, namely, their ability to be used as linguo-cognitive means of creating humorous effects. This aspect is further discussed by Elena Stoyanova's in her paper, where she analyses the use of metaphors in modern Bulgarian mass media which aim to create humorous effects.

Interesting data are analysed in Alla Kornienko's paper which discusses the results of the annual "Word of the Year" contest held in Russia since 2007 by the Russian-speaking Internet community. The winners of the contest are the words which have gained popularity over a certain period and which reflect current political trends and refer to events which have an influence on the life of everyone in Russia (e.g., reforms of the healthcare system or the pension scheme). The majority of the words also bear a strong evaluative component, and the connotation is mostly negative. A specific subcategory of the Word of the Year contest are neologisms or nonce-words created as oxymorons or portmanteau words which unite incompatible concepts and create a humorous effect. Since the wordplay is a clear sign of ridicule and criticism towards authorities, the words reflect the true mindset of the Russianspeaking online community.

Galina Ryabova and Maria Vorobyeva's papers turn the readers' attention to the practices of the mass media of the Soviet era. Galina Ryabova discusses humour and satire in everyday life of Soviet people in the 1920s. There were two types of humorous discourse: the official and the unofficial ones. While at the unofficial level humour existed predominantly in the forms of canned jokes, funny couplets and witty-ditties, the official humour existed in mass media and it was also performed by various propaganda groups or theatres. The circulation figures of satirical magazines reflected their popularity. The analysis of publications shows that in the 1920s the main targets of humour and satire were intellectuals, priests and private entrepreneurs. One of the most popular genres of the official humour was political caricature. The drawings were often rude and aggressive towards politicians whose views diverged from the Soviet ideology. The paper also discusses the agitprop theatre Sinaya Bluza as a specific form of official Soviet humour in the 1920s.

Maria Vorobyeva's paper is also devoted to the Soviet period. It presents a case study of the Soviet satirical cinemagazine Fitil [The Fuse] as an example of the Soviet policy in the sphere of humour and comedy. The cinemagazine was an important part of the mainstream satire, which supported and reinforced the state policy and, at the same time, denounced its drawbacks (e.g., deviation from social norms of the Soviet society, bureaucracy, low quality of products, bad service in retail and catering or alcohol addiction) in a humorous manner. The analysis demonstrates the evolution of humour and mild irony of Fitil in the 1960s to grotesque and absurdity in the 1970s and 1980s. Grotesque was the technique which allowed for presenting the targets of satire to be as gross as possible. Despite the cinemagazine being heavily censored by the authorities, it created an illusion of political criticism and as such Fitil was an organic part of the general Soviet policy in the sphere of humour and comedy. 


\section{References}

Attardo, S. (ed.) (2017). The Routledge Handbook of Language and Humor. New York, NY: Routledge.

Attardo, S. (2020). "Memes, memeiosis, and memetic drift: Cheryl's Chichier She Shed'. Медиалингвистика, 7 (2), 146-168. https://medialing.ru/memes-memeiosisand-memetic-drift-cheryls-chichier-she-shed/ (accessed: 28.03.2021)

Brzozowska, D., Chłopicki, W. (2020). 'April Fools' day news - Still funny?’ Медиалингвистика, 7 (2), 184-192. https://medialing.ru/april-fools-daynews-still-funny/ (accessed: 28.03.2021)

Duskaeva, L. R., Shcheglova, E. A. (2020). 'Vospriyatie komicheskogo teksta-pranka v dialoge setevogo obshcheniya: postanovka problem' [Perception of a comic text-prank in the dialogue of network communication: Creating a problem]. Media Linguistics 7 (2), pp. 238-249. Available at: https://medialing.ru/vospriyatie-komicheskogo-teksta-prankav-dialoge-setevogo-obshcheniya-postanovka-problemy/ (accessed: 28.03.2021). (In Russian)

Filani, I. (2016). 'Laf wan kill me die' (I almost died laughing): an analysis of Akpos jokes and the readers' responses'. The European Journal of Humour Research 4 (4), pp. 5-25.

Grochala, B. (2014). 'Humor polski w globalnej sieci', in Brzozowska, D. \& Chłopicki, W. (eds.), Humour and Culture 4: Humor polski. Kraków: Tertium, pp.301-319.

Grochala, B.\& Dembowska-Wosik, I. (2012). 'Humour in the global network', in Brzozowska, D. \& Chłopicki, W. (eds.) Humour and Culture 2: Polish Humour. Kraków: Tertium, pp.257-267.

Kostomarov, V. G. (1971) Russkij âzyk na gazetnoj polose: nekotorye osobennosti âzyka sovremennoj gazetnoj publicistiki [Language on the newspaper page: some features of the language of modern newspaper journalism]. Moskva: Izdat. moskovskogo universiteta.

Laineste, L.\&Voolaid, P. (2016). 'Laughing across borders: intertextuality of internet memes'. The European Journal of Humour Research 4 (4), pp. 26-49.

Marone, V. (2015). 'Online humour as a community-building cushioning glue'. The European Journal of Humour Research 3 (1), pp. 61-83.

Marone, V. (2016). 'Looping out loud: a multimodal analysis of humour on vine'. The European Journal of Humour Research 4 (4), pp. 50-66.

Mifdal, M. (2016). 'Digital politics on Facebook during the Arab Spring in Morocco: adaptive strategies of satire relative to its political and cultural context'. The European Journal of Humour Research 4 (3), pp. 43-60.

Pahl, B. (2016). 'Pussy Riot's humour and the social media: self-irony, subversion, and solidarity'. The European Journal of Humour Research 4 (4), pp. 67-104.

Steir-Livny, L. (2016). 'Is it ok to laugh about it yet? Hitler Rants YouTube parodies in Hebrew'. The European Journal of Humour Research 4 (4), pp. 105-121.

Stoyanova, E. (2015) Metafora kak sposob osmyslyeniya sovremennoy deystvitelnosti [Metaphor as a way of understanding contemporary reality]. Media Linguistics, No. 4 (10), pp. 60-66. Available at: https://medialing.ru/metafora-kak-sposob-osmysleniyacovremennoj-dejstvitelnosti/ (accessed: 10.05.2020). (In Russian)

Tay, G. (2014). 'Binders full of LOLitics: Political humour, internet memes, and play in the 2012 US Presidential Election (and beyond)'. The European Journal of Humour Research 2 (4), pp. 46-73.

Vásquez, C. (2019) Language, Creativity and Humour Online. Routledge.

Vasileva, V. (2017). 'Anekdot v professional'nom mediatekste: pereprofilirovanie rechevogo zhanra' [Anecdote in professional media text: re-profiling of the speech genre]. Media 
Linguistics, 4 (19), pp. 80-89. https://medialing.ru/anekdot-v-professionalnommediatekste-pereprofilirovanie-rechevogo-zhanra/ (In Russian)

Vasileva, V. (2019). 'Prosodic text rhythm and comic effects: The possibility of correlation.' http://www.iefpg.org.rs/Conference/2019/S\&L2019_PROCEEDINGS.pdf.

Vasileva, V. \& Ivanova, L. (2020) 'Shutlivayatonal'nost' kak instrument organizacii vzaimodejstviya $\mathrm{v}$ novostnom televizionnom kommunikate' [Facetious tone as a technique for organisation of interaction in a news television communicate]. Media Linguistics 7 (2). (In Russian).

Vasileva, V. \& Ivanova, L. (2021). 'Speech etiquette of professional online communities' Russian Journal of Communication, 1940-9419.

Weitz, E. (2016). 'Editorial: humour and social media'. The European Journal of Humour Research 4 (4), pp. 1-4.

Weitz, E. (2017). 'Online and internet humor', in Attardo, S. (ed.), The Routledge Handbook of Language and Humor. New York, NY: Routledge, pp. 504-518. 